\title{
Loss of Zona Pellucida in Mouse Unfertilized Eggs
}

\author{
Hirotada TsujiI \\ Laboratory of Animal Breeding and Reproduction Faculty of Agriculture, \\ University of Shinshu Minamiminowa-mura, Kamiina-gun, 399-45, Japan
}

(Accepted for publication May 25, 1988)

\begin{abstract}
Summary. Present investigation was carried out to examine whether the loss of zona pellucida occurs in unfertilized eggs of mice during the estrous cycle and pseudopregnancy. A total of 1271 eggs were recovered from the oviducts and uterus by flushing with modified K.R.B. solution between $10: 00 \mathrm{~h}$ on day 3 and $10: 00 \mathrm{~h}$ on day 4 of the estrous cycle at $3 \mathrm{~h}$ intervals (day $1=$ day of estrus). Also 190 eggs were collected between at $5: 00 \mathrm{~h}$ on the 4 th day of pseudopregnancy and at 3:00 h on the following day at $2 \mathrm{~h}$ intervals. The percentage of unfertilized eggs without the zona pellucida were $2 \%(25 / 1271)$ in cyclic mice and $0.5 \%(1 / 190)$ in pseudopregnant mice. KEY WORDS; LOSE OF ZONA PELLUGIDA, UNFERTILIZED EGG, MOUSE.
\end{abstract}

Jpn J Anim Reprod 34, 261-263, 1988

\section{マウス未受精卵における透明帯の剝離について}

\author{
过井 弘忠 \\ 信州大学農学部, $\mathbf{T} 399-45$ 長野県上伊那郡南箕輪村 8304
}

マウスおよびラットの未受精卵子の多くは退化過程に 分割を行って，最終的には発情期の子宮液と共に臸外 排出される (Blandau, 1943; 石橋, 1962)。その過程に Mann（1924）及び石橋（1962）はラットで, Charlton (1917)はマウスで一部の未受精卵子の透明帯剝離したも のがあることを観察しているが， McLaren and Orsini (1968)はマウスでこれらの事実を否定している。本実験 はマウス未受精卵子において透明带の剝離が特こるか否 かを確かめると共にその割合について調べることを目的 として行った。

材料と方法: 供試動物は $6 \sim 7$ 週齢の ICR 系未経産 マウスを午前 6 時点灯, 12 時間明暗の条件下で市販の固 形飼料と水を自由摂取させて飼育した。性周期中の未受 精卵子の観察は, 㓐垢像が発情期を示した日を第 1 日と して，第 3 日の午前10時から 4 日午前10時の間 3 時間毎 に 137 頭のマウスから採卵を行った。偽妊娠中の未受精 卵子の観察は窑垢像が発情前期を示した夕方, 精管結禁 した雄マウスと同居させ, 翌朝腔栓の有無により㑇妊娠
の成立を確認して行った(偽妊娠第 1 日)。偽妊娠第 4 日 の午後 1 時から 5 日の午後 3 時までの間 2 時間毎に 19 頭 から採卵した。

採卵は修正 Krebs-Ringer-bicarbonate 液を用いて, 畉管および子宮の灌流によった。採卵後加温実体顕微鏡 及び倒立位相差顕微鏡下で卵子数とその形態（未分割等 又は不等分割）及び透明帯の有無について観察した。ま た, 灌流液中に剝離した透明帯や卵子の割球の断片が存 在するか否かについても観察した。

結果と考察 : 本実験に供したマウスの平均排卵数は 12.0であった。経時的に採取した未受精卵の採卵部位及 び形態別の成績は Table 1 に示した。観察期間内の未 受精卵の形態別内訳は, 等分割卵はなく, 不等分割卵が

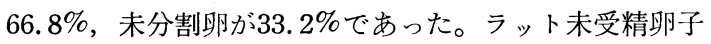
は排卵後, 経時的に分割卵の割合が増加することが報告 されているが (Charlton, 1917; 石橋, 1961), 本実験に おいても同様の傾向がみられた。未受精卵子の子宮への 到達は性周期第 3 日の 10 時に始まり, それ以後経時的に 
Table 1. The recovery and location of unfertilized eggs in mice

\begin{tabular}{|c|c|c|c|c|c|c|c|c|}
\hline \multicolumn{2}{|c|}{ Time of observation } & \multirow{2}{*}{$\begin{array}{c}\text { No. of } \\
\text { Females }\end{array}$} & \multicolumn{3}{|c|}{ Total no. of eggs recovered from } & \multirow{2}{*}{$\begin{array}{l}\text { Average no. } \\
\text { of eggs } \\
\text { recovered }\end{array}$} & \multicolumn{2}{|c|}{ No of eggs } \\
\hline Day* & $\mathrm{Hr}$ & & Oviduct & Uterus & Total & & 1-celled & Fragmented \\
\hline \multirow[t]{5}{*}{3} & 10 & 14 & 152 & 1 & 153 & $10.6 \pm 4.0$ & 43 & 110 \\
\hline & 13 & 17 & 185 & 13 & 198 & $11.6 \pm 3.4$ & 79 & 119 \\
\hline & 16 & 16 & 139 & 37 & 176 & $10.6 \pm 4.5$ & 64 & 112 \\
\hline & 19 & 15 & 157 & 36 & 193 & $12.6 \pm 3.9$ & 62 & 131 \\
\hline & 22 & 16 & 95 & 79 & 174 & $11.3 \pm 4.6$ & 63 & 111 \\
\hline \multirow[t]{4}{*}{4} & 01 & 13 & 63 & 73 & 136 & $11.5 \pm 3.5$ & 41 & 95 \\
\hline & 04 & 15 & 32 & 66 & 98 & $6.6 \pm 6.0$ & 35 & 63 \\
\hline & 07 & 13 & 8 & 66 & 74 & 5.8 土. 5.9 & 20 & 54 \\
\hline & 10 & 18 & 6 & 63 & 69 & $3.8 \pm 4.7$ & 15 & 54 \\
\hline Total & & 137 & 837 & 434 & 1271 & $9.2 \pm 5.5$ & 422 & 849 \\
\hline
\end{tabular}

* Day $=$ day of estrous $M_{ \pm S}$. D.

Table 2. Incidence of loss of zona pellucida in unfertilized mouse eggs

\begin{tabular}{|c|c|c|c|c|c|c|c|c|c|}
\hline \multirow{2}{*}{\multicolumn{2}{|c|}{ Time killed }} & \multirow{3}{*}{$\begin{array}{r}\text { No. of } \\
\text { females }\end{array}$} & \multirow{3}{*}{$\begin{array}{l}\text { No. of eggs } \\
\text { recovered }\end{array}$} & \multicolumn{4}{|c|}{ No. of eggs without zona pellucida } & \multirow{2}{*}{\multicolumn{2}{|c|}{$\begin{array}{l}\text { No. of vacant } \\
\text { zona pellucida }\end{array}$}} \\
\hline & & & & \multicolumn{2}{|c|}{$1-$ celled } & \multicolumn{2}{|c|}{ Fragmented } & & \\
\hline Day* & $\mathrm{Hr}$ & & & Oviduct & Uterus & Oviduct & Uterus & Oviduct & Uterus \\
\hline \multirow[t]{5}{*}{3} & 10 & 14 & 153 & 0 & 0 & 4 & 0 & 6 & 0 \\
\hline & 13 & 17 & 198 & 4 & 0 & 0 & 0 & 2 & 0 \\
\hline & 16 & 16 & 176 & 3 & 0 & 0 & 0 & 1 & 0 \\
\hline & 19 & 15 & 193 & 5 & 0 & 1 & 0 & 2 & 0 \\
\hline & 22 & 16 & 174 & 2 & 2 & 0 & 0 & 6 & 0 \\
\hline \multirow[t]{4}{*}{4} & 01 & 13 & 136 & 1 & 0 & 0 & 0 & 2 & 3 \\
\hline & 04 & 15 & 98 & 2 & 0 & 0 & 0 & 0 & 0 \\
\hline & 07 & 13 & 74 & 1 & 0 & 0 & 0 & 2 & 0 \\
\hline & 10 & 18 & 69 & 0 & 0 & 0 & 0 & 0 & 0 \\
\hline Total & & 137 & 1271 & 18 & 2 & 5 & 0 & 21 & 3 \\
\hline
\end{tabular}

* Day $1=$ day of estrous.

子宮内卵子の割合が増加した。この下降速度は受精卵子 の場合（辻井, 伊藤, 1986) より速く, ラット（利部, 石 橋, 1977; Villalou et al., 1982) も同様の傾向であっ た。

形態別にみた透明帯の剝離した未受精卵子の割合は Table 2 に示した。性周期第 3 日の10時から 4 日の 7 時 までの間に透明带の剥離した卵子は25個( $2 \%)$, 剝離し た透明帯は24個であった。また，透明帯の剝離した卵子 及び䟝離した透明帯の殆ど(23/25および21/24)は卵管内 で観察された。さらに，透明帯が剥離したことによって 分割卵の割球が灌流液中に散在しているものは，性周期 第 3 日の 10 時に 4 例, 19時に 1 例観察され, 䟝離した透 明帯には琶裂がみられた。

McLaren and Orsini (1968) は，マウス未受精卵にお
いて透明带の剝離した卵子が観察されなかったことか ら，Charlton(1917)の結果は固定による剥離であり，仮 に未受精卵に扮いて透明帯の剝離があるとすればバラバ ラになった割球が観察されるはずであると述べている。 本実験は無固定で剥離した透明帯とバラバラになった割 球を観察しているので，低い割合ではあるが未受精卵に 透明带剝離が起りらることは明らでかある。同様のこと はラット未受精畉の透明帯剝離に関しても（Blandau, 1943；石橋，1962）報告されている。

偽妊娠マウスに㧍ける透明带の剥離した卵子の割合は Table 3 に示した。採卵した未受精卵は等分割卵がな く, 不等分割卵が $42.6 \%$ ，未分割卵が $57.4 \%$ 存在した。 偽妊娠 4 日目の13時に透明带剝離した未受精卵と透明带 が各 1 個観察された。また，性周期の第 4 日 4, 7，10 
Table 3. The recovery and location of unfertilized eggs in pseudopregnant mice

\begin{tabular}{|c|c|c|c|c|c|c|c|c|}
\hline \multicolumn{2}{|c|}{ Time of observation } & \multirow{2}{*}{$\begin{array}{c}\text { No. of } \\
\text { Females }\end{array}$} & \multicolumn{3}{|c|}{ Total no. of eggs recovered from } & \multirow{2}{*}{$\begin{array}{l}\text { Average no. } \\
\text { of eggs } \\
\text { recovered }\end{array}$} & \multicolumn{2}{|c|}{ No. of eggs } \\
\hline Day* & $\mathrm{Hr}$ & & Oviduct & Uterus & Total & & 1-celled & Fragmented \\
\hline \multirow[t]{4}{*}{4} & 17 & 2 & 0 & 19 & 19 & 9.5 & 6 & 13 \\
\hline & 19 & 2 & 0 & 20 & 20 & 10.0 & 3 & 17 \\
\hline & 21 & 7 & 2 & 77 & 79 & 11.3 & 57 & 22 \\
\hline & 23 & 2 & 0 & 21 & 21 & 10.5 & 14 & 7 \\
\hline \multirow[t]{2}{*}{5} & 01 & 3 & 0 & 23 & 23 & 7.6 & 7 & 16 \\
\hline & 03 & 3 & 2 & 26 & 28 & 9.3 & 22 & 6 \\
\hline Total & & 19 & 4 & 186 & 190 & $10.1 \pm 2.5$ & 109 & 81 \\
\hline
\end{tabular}

* Day $1=$ day which vaginal plug was found. $M \pm S . D$.

時の各採卵数が $6.6,5.8,3.8$ と低いのに対し, 偽妊娠 の第 4 日17時から 5 日 3 時までの採卵数の平均は 10.1 と

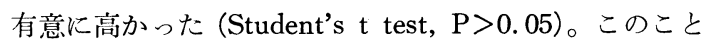
は，偽妊娠によって未受精卵子が子宮内に長く保持され ることを示すが, 同様の結果は偽妊娠マウス (Blandau, 1943; McLaren and Orsini, 1968) 及び 5 日性周期のラ ット(石橋, 1962) で報告されている。なお，偽妊娠マウ スの子宮から採取された未受精卵において，透明帯の部 分で卵子同士が接着しているのが観察された。この接着 は偽妊娠第 4 日の 21 時から認められ, 時間の経過に伴っ て増加する傾向がみられた。このことについて Blandau （1943）は, 脱落膜反応によって子宮腔内の $\mathrm{pH}$ が変化 し，透明帯の粘着性が増すためであろらと述べている。

以上の結果から未受精卵の退化過程に低い割合である が透明帯の剥離するものがあることを知った。しかしな がら, その機序については明らかでなく, 今後の検討を 要する。

\section{References}

Blandau RJ (1943) The fate of the unfertilized ova in the albino rat. Anat Rec 87: 17-27.

Charlton HH (1917) The fate of the unferilized egg in the white mouse. Biol Bull 33: 321-331.

Ishibashi I (1961) Cytological observations on the cleavage of the unfertilized ovum of rat. $J p n J$ Zootech Sci 31: 291-300 (in Japanese).

Ishibashi I (1962) Final fate of the unfertilized ovum of the rat. Jpn J Zootech Sci 32: 339-343 (in Japanese).

Kagabu S, Ishibashi I (1977) Effect of HCG treatment on the transport of ova in adult rats. Jpn J Anim Reprod 23: 153-158 (in Japanese).

Mann MC (1924) Cytological changes in unfertilized tubal eggs of the rat. Biol Bull 46: 316-327.

McLaren A, Orsini MW (1968) The fate of unfertilized eggs in mice. J Reprod Fer 15: 181-183.

Tsujii H, Itoh S (1986) Relationship between delayed implantation and loss of the zona pellucida in the mouse blastocyst. J Mamm Ova Res 3: 122-127 (in Japanese).

Villalón M, Oritiz ME, Aguayo C, Munóz J, Croxatto HB (1982) Differential transport of fertilized and unfertilized ova in the rat. Biol Reprod 26: 337341 .

\section{要 約}

ICR 系マウスを用いて，未受精卵の透明帯が，剝離するか否かについて調べた。その結果，性周 期中の 137 頭のマウスから経時的に採取した 1271 個の未受精卵では，透明帯の剝離した卵子は 25 個 ( $2 \%)$ であり，偽妊娠マウスでは 190 個のらち 1 個であった。このことから，低い割合ではあるが未 受精卵子に透明带の剝離が起こることが明らかとなった。 